University of New Hampshire

University of New Hampshire Scholars' Repository

$12-1992$

\title{
Downhole Logging as a Paeoceanographic Tool on Ocean Drilling Program Leg 138: Interface Between High-Resolution Stratigraphy and Regional Syntheses
}

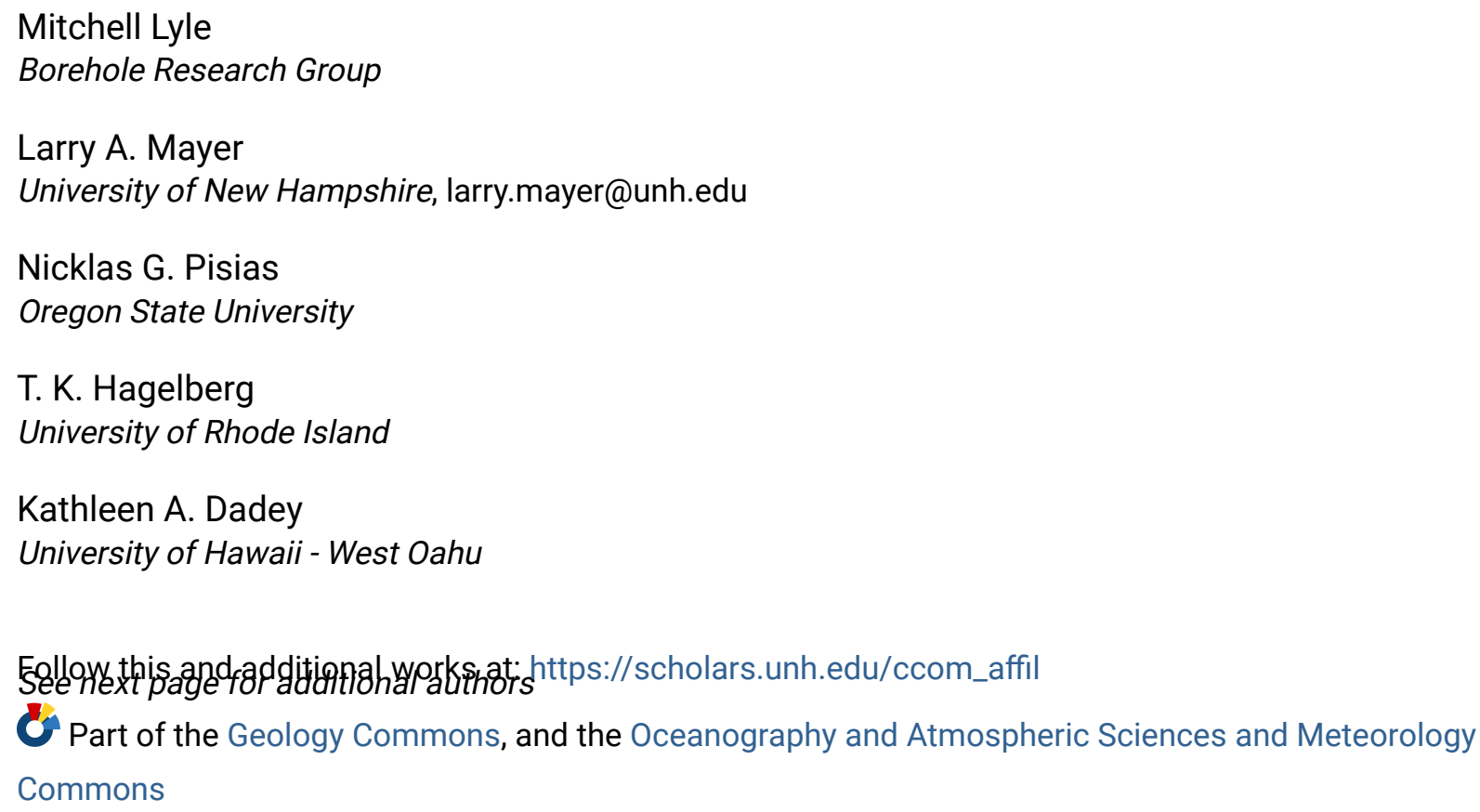

\section{Recommended Citation}

M. Lyle, L. Mayer, N. Pisias, T. Hagelburg, K. Dadey, and S. Bloomer, 'Downhole Logging as a Paeoceanographic Tool on Ocean Drilling Program Leg 138: Interface Between High-Resolution Stratigraphy and Regional Syntheses', Paleoceanography, vol. 7, no. 6, pp. 691-700, Dec. 1992.

This Article is brought to you for free and open access by the Center for Coastal and Ocean Mapping at University of New Hampshire Scholars' Repository. It has been accepted for inclusion in Affiliate Scholarship by an authorized administrator of University of New Hampshire Scholars' Repository. For more information, please contact Scholarly.Communication@unh.edu. 


\section{Authors}

Mitchell Lyle, Larry A. Mayer, Nicklas G. Pisias, T. K. Hagelberg, Kathleen A. Dadey, Stephen F. Bloomer, and Shipboard Scientific Party 


\section{PALEOCEANOGRAPHIC CURRENTS}

PALEOCEANOGRAPHY, VOL. 7, NO. 6, PAGES 691-700, DECEMBER 1992

\author{
DOWNHOLE LOGGING AS A PAEOCEAN- \\ OGRAPHIC TOOL ON OCEAN DRILLING \\ PROGRAM LEG 138: INTERFACE \\ BETWEEN HIGH-RESOLUTION \\ STRATIGRAPHY AND REGIONAL \\ SYNTHESES
}

Mitchell Lyle, ${ }^{1}$ Larry Mayer, ${ }^{2}$ Nicklas Pisias, ${ }^{3}$ Terri Hagelburg, ${ }^{3}$ Kathy Dadey, ${ }^{4}$ Stephen Bloomer, ${ }^{2}$ and the Shipboard Scientific Party of Leg 138 determine where the distortion occurred and to correct back to true in situ depths.

Downhole logging also provides a means, through the generation of synthetic seismograms, of precisely relating the paleoceanographic events found in the core record to the high-resolution seismic record. Once correlated to the seismic record, the spatial and temporal extent of paleoceanographic events can be traced well beyond the borehole. Most seismic events in the equatorial Pacific are related to rapid changes in carbonate content that, in turn, are related to both productivity events (often expressed as monospecific laminated diatom oozes) and times of enhanced dissolution. While many of these events may have oceanwide extent, others, like the absence of carbonate in the late-Miocene to Recent in the Guatemala Basin have been shown to be regional and confined to only the deeper portions of the Guatemala Basin. As we identify and trace specific paleoceanographic events in the seismic record, we can begin to explore the response of the ocean through gradients of latitude, productivity, and depth.

\section{INTRODUCTION}

High-resolution (i.e., time scales of a thousand years or less) paleoceanographic studies have provided important insight into the oceans' response to Milankovitch-type variations in solar insolation or other climatic responses of even higher frequency. Limitations of coring technology have, for the most part, restricted these extremely high resolution studies to the 
Pleistocene as it has been virtually impossible to obtain the detailed stratigraphic resolution necessary to carry out high-resolution studies on long, pre-Pleistocene ocean drilling cores. Recent improvements in the technology used to recover marine sedimentary sections with ocean drilling, however, as well as newly developed methods for the detailed measurement of the physical properties and chemical composition of sedimentary materials are rapidly removing these limitations. Here we will describe how downhole logging plays a critical role in providing additional stratigraphic control for paleoceanographic studies and establishing a link between discrete physical property measurements made on cores and underway seismic reflection profiles. In providing this link, downhole logging thus becomes a key element in using the seismic record to establish the areal extent of major paleoceanographic events.

\section{CORING ON OCEAN DRILLING PROGRAM (ODP) LEG 138}

One of the major constraints on recovering long, continuous high-resolution stratigraphic records from ocean drilling cores has been the well-known occurrence of gaps in the sediment record as well as the occasional occurrence of double-cored intervals [Heath et al., 1985; Ruddiman et al., 1987]. With a knowledge of the problems associated with core breaks and a desire to obtain the most complete sections possible, the leg 138 scientific party adopted a strategy to find core discontinuities while the drill site was still occupied and while there was an opportunity to recover previously "missed" sections. Specialized software was developed to monitor the output of laboratory core scanning systems that make centimeter-scale measurements of several physical properties (saturated bulk density, magnetic susceptibility, and digital color reflectance spectroscopy) on sediment cores immediately after their retrieval from the seafloor. This information was used to guide the drillers and ensure that the core breaks were offset in the second and third holes drilled at a site. In this fashion a complete sedimentary section was spliced together at most drill sites. A comparison of saturated bulk density records (determined with the gamma ray attenuation porosity evaluator (GRAPE)) from two offset holes at site 849 shows that nearly continuous recovery can be achieved even in the indurated sedimentary section older than $6 \mathrm{Ma}$ where the section was drilled with the extended core barrel (XCB); (Figure 1). Similar correlations between cores from offset drill holes can be made with the continuous magnetic susceptibility and

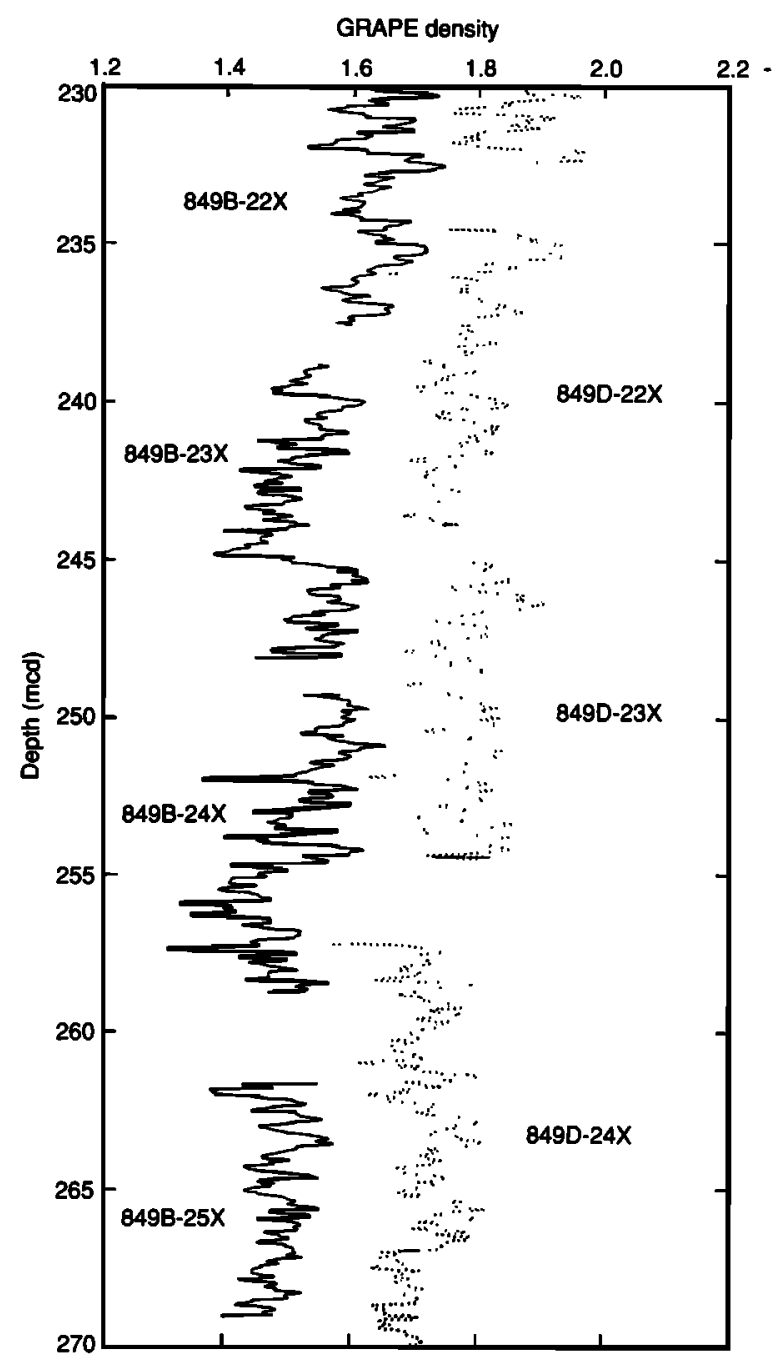

Fig. 1. An example from ODP site 849 of how the composite gamma ray attenuation porosity evaluator (GRAPE) bulk density section is constructed. Each segment on the figure represents a separate drill core; solid lines represent data from a different hole than the dashed line. The cores have been shifted so that correlated peaks match in depth. The data from the two cores have been offset for clarity. Gaps of 2 or $3 \mathrm{~m}$ between cores were common in this $\mathrm{XCB}$ (extended core barrel sampler) section, while in the upper sediments cored by APC (advanced piston core sampler), gaps were typically much smaller.

digital color profiles also collected on leg 138 (Figure 2). The location of unrecovered sections and the mass and types of sediments missing from the spliced core profiles were then estimated by comparison to downhole logs (for example, site 846 in Figure 3). 
Site 844 - Composite Summary

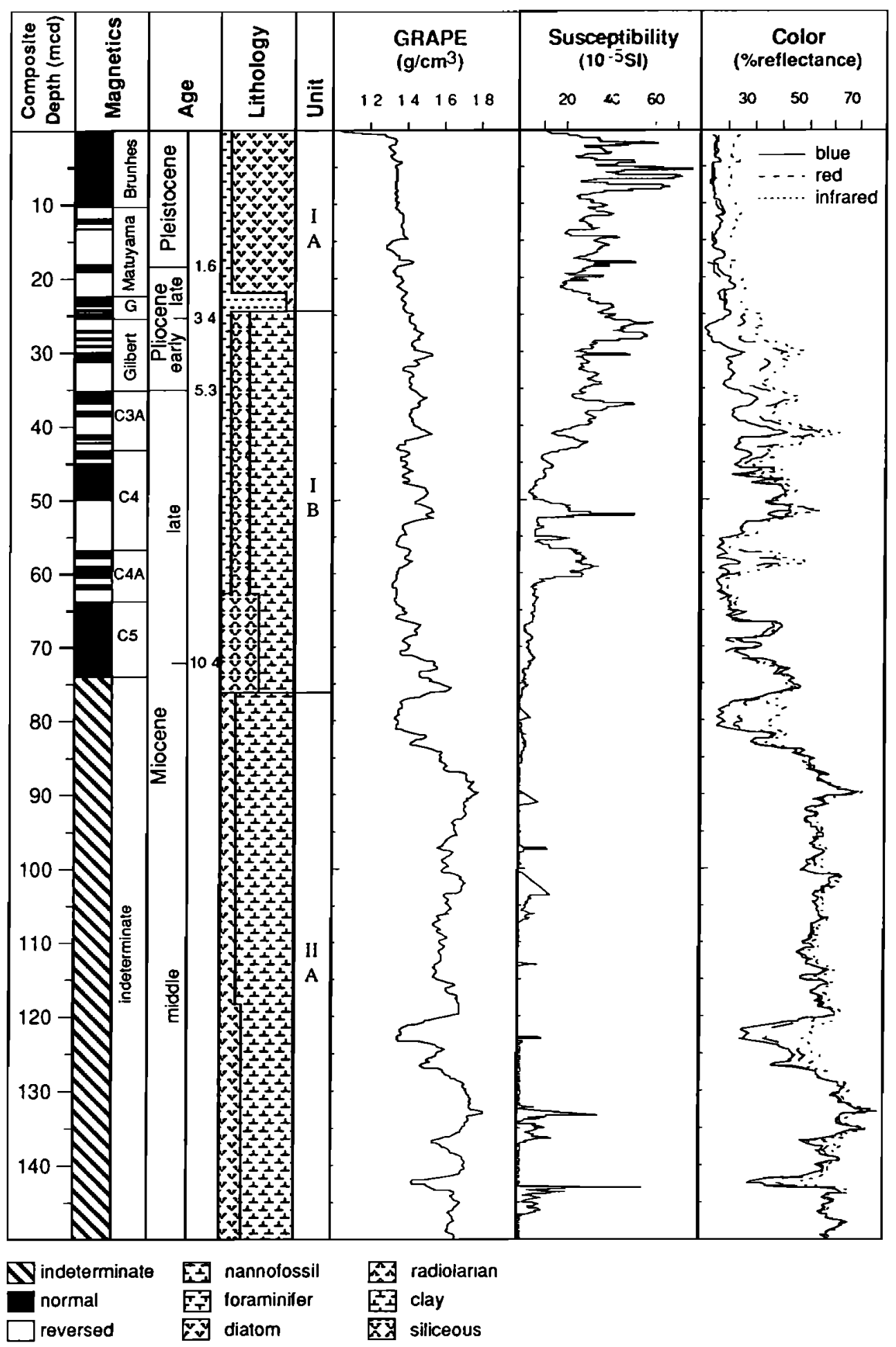

Fig. 2. Summary of lithology, magnetics, stratigraphy, GRAPE, susceptability, and color reflectance data for the upper $150 \mathrm{~m}$ of ODP leg 138 site 844 . 


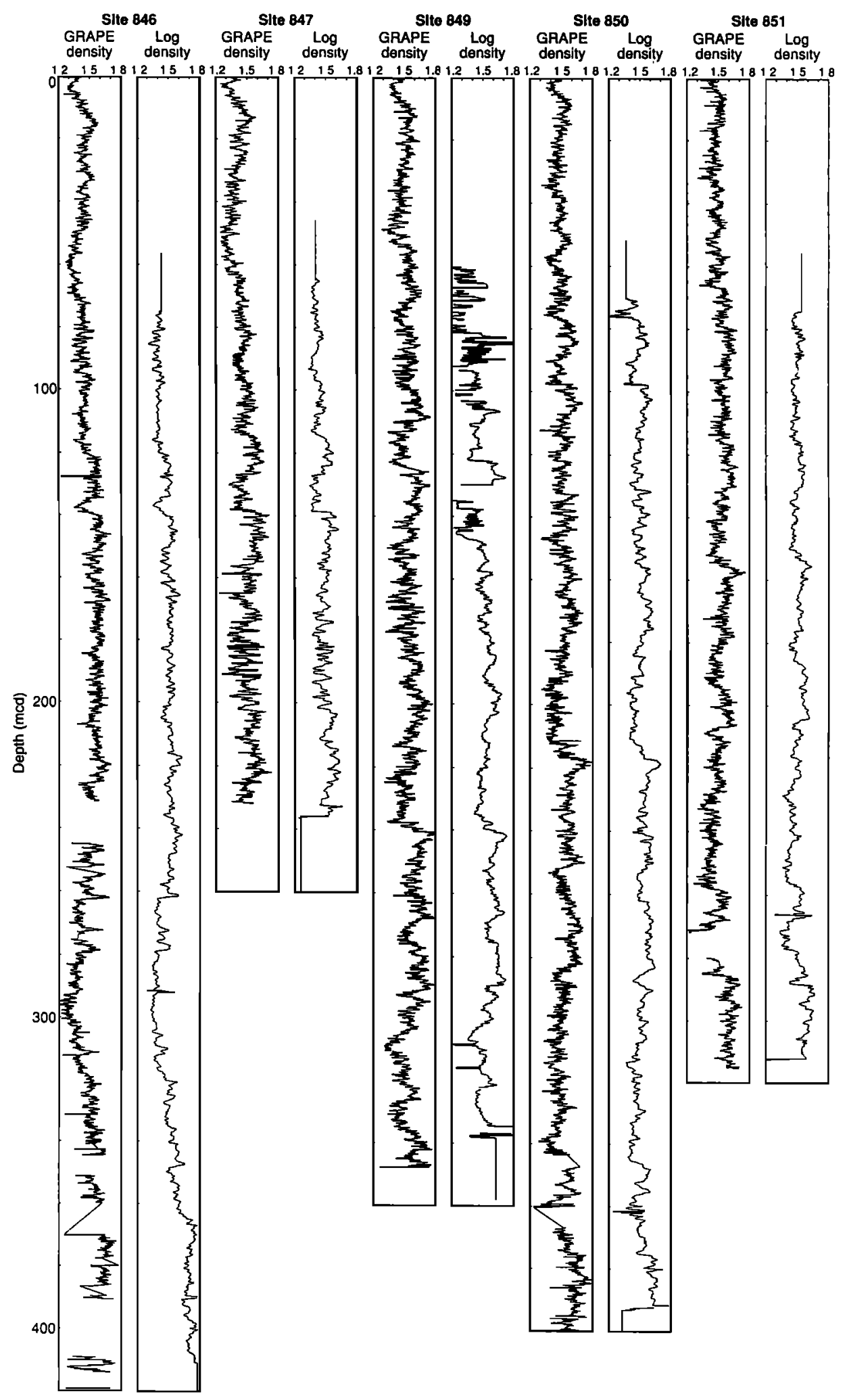

Fig. 3. Comparison of core bulk density profiles, depth shifted to match logging data measured in situ at leg 138 sites. Logs provide a means to correct for coring-induced distortions. 


\section{DOWNHOLE LOGGING TO EVALUATE CORE RECOVERY}

During ODP leg 138 we found that the spliced continuous sediment section was typically about $10 \%$ longer than the section drilled, as measured by the drill string. Corrections for this poorly understood phenomenon must be made in order to place the paleoceanographic data within the original depth framework and to properly determine sedimentation and mass accumulation rates. Downhole logging at each ODP drill site provided the means to determine where the distortion had occurred, because the downhole logs measured, in situ, many of the same physical properties that we measured on the recovered cores. We can then use inverse correlation methods [Martinson et al., 1982] to map events from the composite sedimentary section assembled from cores to the continuous record measured downhole by logging instruments.

Profiles of shipboard composite bulk density and the bulk density measurements measured by logging tools are similar, although the logging profile is smoothed by the innate tool response
(Figure 3). The shipboard composite depths have been shifted to match log data by simple linear transformations. While most of the distortion of the composite record has been removed by this correction, second-order distortions can still be found. High-resolution flux studies will therefore require nonlinear adjustments to the depth scale.

Comparisons between the downhole logging record of saturated bulk density and the laboratory determined record also allows us to explore possible causes of the $10 \%$ elongation of the recovered section. If the material had simply been stretched by $10 \%$ during recovery, then density of core material should be about $10 \%$ lower than the density measured downhole. Instead, we found an average density differences between logging and shipboard measurements of about 5\%. Sedimentary rebound by decompression as the cores are removed from their subseabed position to the lab is insufficient to cause the stretch we observe - it should have caused stretch of less than 5\% of the core length (4.5\% in calcareous sediments $300 \mathrm{~m}$ below the seafloor) [Hamilton, 1976]. We are left with the possibility that the coring process may both subtly compress and lengthen the recovered

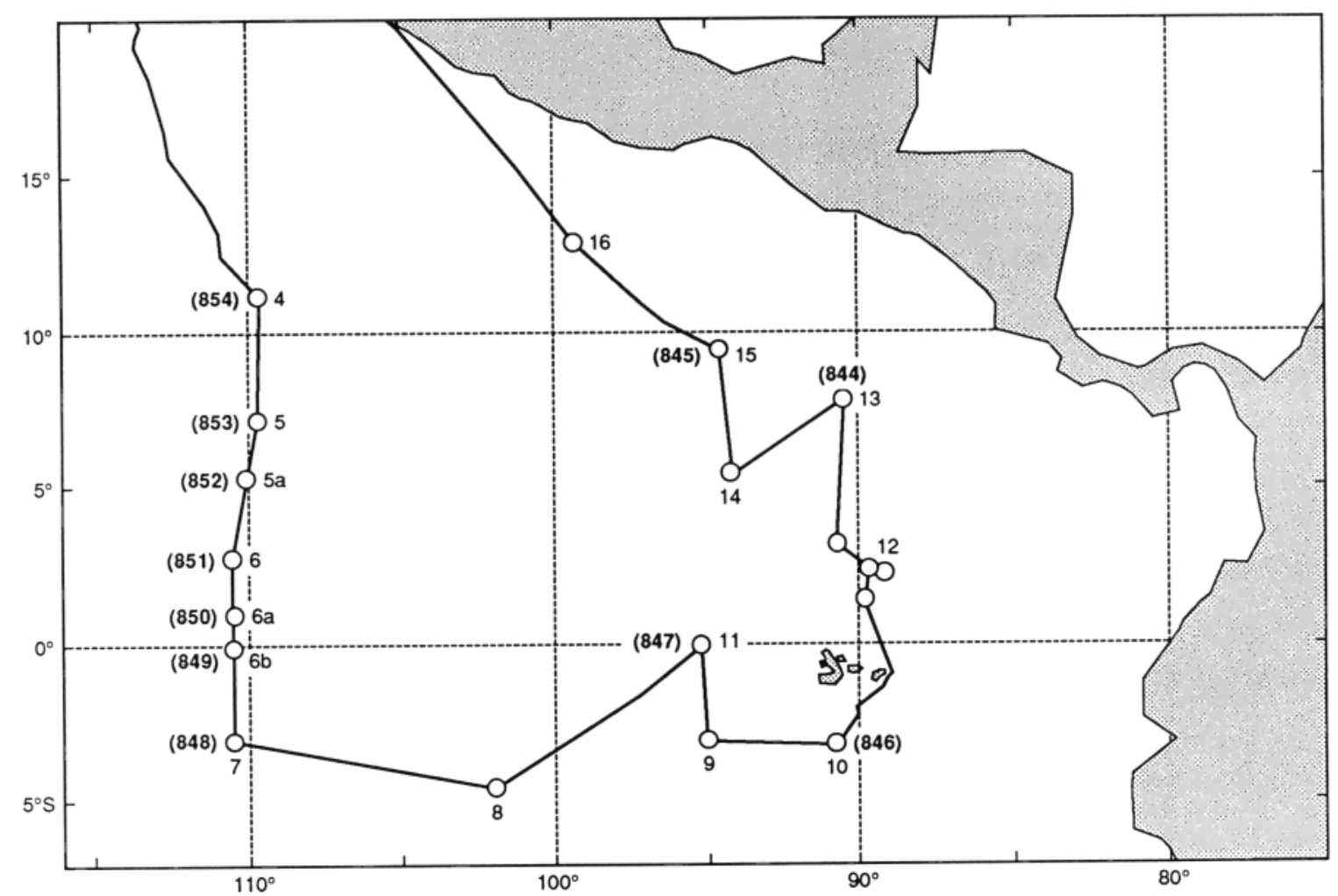

Fig. 4. Track of R/V Thomas Washington on the leg 138 site survey cruise, Venture 01. Leg 138 drill sites are also shown. 
cores, as if the sediment had been squeezed through a die during coring.

\section{DOWNHOLE LOGGING AND CALIBRATION OF THE SEISMIC SECTION}

Downhole logging also provides a critical interface between the paleoceanographic results obtained at individual drill sites and the highresolution seismic record, which, if property interpreted, can offer a regional overview of the distribution of paleoceanographic events [Tucholke and Mountain, 1979; Tucholke, 1981; Miller and Tucholke, 1983; Mayer et al, 1986]. As with all ODP legs, a predrilling survey was conducted at all potential leg 138 sites. Included in this survey was the collection of singlechannel, digital seismic data (80 cubic inch watergun) along a track that connected each of the sites drilled on leg 138 (Figure 4). Site survey data are typically used to assure that the site is located where the section is as complete as possible and free of slumps and faults. This is the classic use of the seismic record as a structural tool, providing detail of the geometric relationships amongst the sedimentary units profiled. An important goal of leg 138 was to extend our understanding of the seismic record in the eastern tropical Pacific in order that seismic reflection profiles can be used as regional paleoceanographic tools.

Despite the visual similarities between seismic profiles and geologic cross-sections, there is not necessarily a one-to-one correspondence between seismic reflectors and sedimentary layers. Two factors limit our ability to directly interpret the seismic record in terms of geologic layering: (1) the seismic record is a function of seismic travel time and not depth below the seafloor; and (2) the seismic profile is, in essence, an interference composite between fine-scale geologic layering and a limited-resolution seismic pulse. Downhole logging plays a key role in resolving both of
$\mathbf{A}$

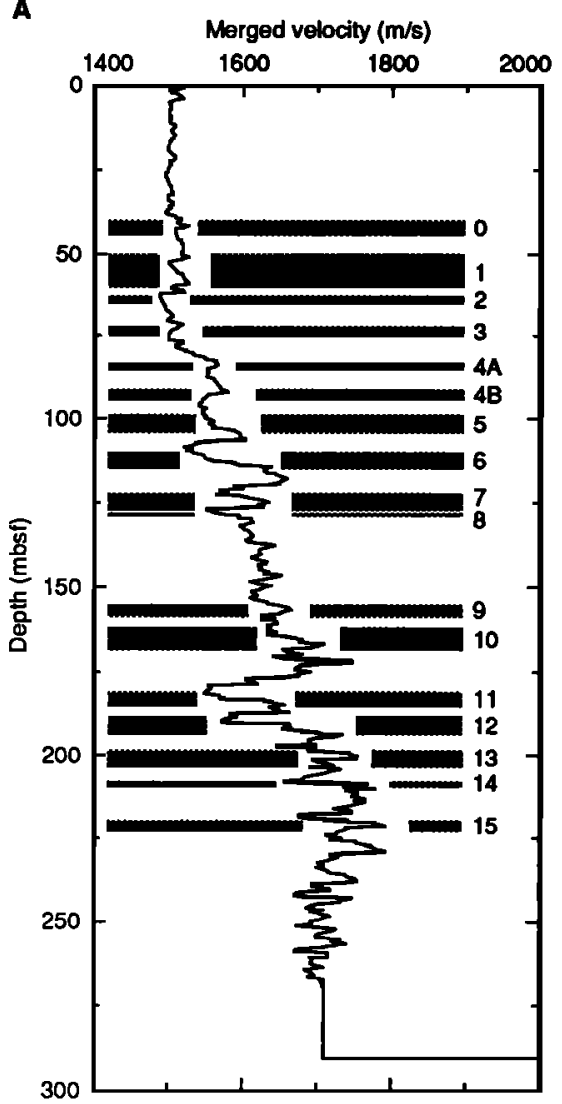

B

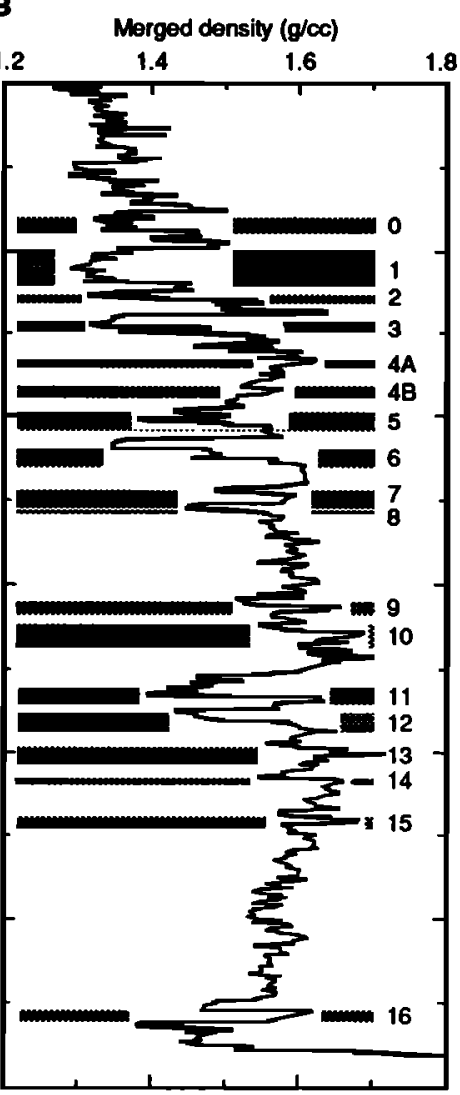

C
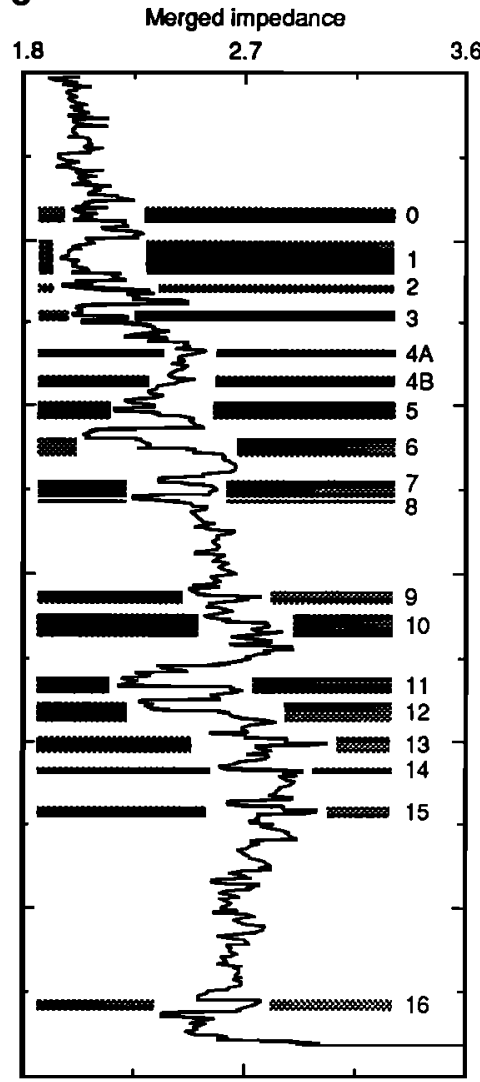

Fig. 5. (a) Merged laboratory (upper $65 \mathrm{~m}$ ) and downhole log velocity measurements at ODP site 844; (b) merged laboratory (upper $65 \mathrm{~m}$ ) and downhole log saturated bulk density measurements at ODP site 844; (c) calculated acoustic impedance profile for ODP site 844. Shaded lines show major seismic reflectors picked on Figure 6. 
these problems and improves our ability to interpret the seismic profile in terms of geologic phenomena.

To relate drilling results to the seismic record, we must first convert seismic travel times to depths. This conversion implies a knowledge of the in situ velocity, a parameter directly measured with downhole logging. In the upper $50-100 \mathrm{~m}$ of the sedimentary section where no downhole logging data are collected because of borehole stability problems, we use shipboard laboratory measurements of sonic velocity. These velocities are not in situ measurements, but we use comparisons of downhole logging and laboratory measurements deeper in the section (where they overlap) to determine corrections needed to convert laboratory values to in situ values. We thus construct a complete profile of in situ velocity versus depth (Figure 5a) which then becomes the basis for converting seismic travel time to depth and allows us to determine where in the borehole a particular reflector is located (Figures 5 and 6 ).

To understand the nature of the interaction of the outgoing seismic pulse and the sedimentary structure, we also use downhole logging results to produce the data needed to generate a synthetic seismogram. A profile of in situ saturated bulk density is constructed from downhole logging measurements and corrected
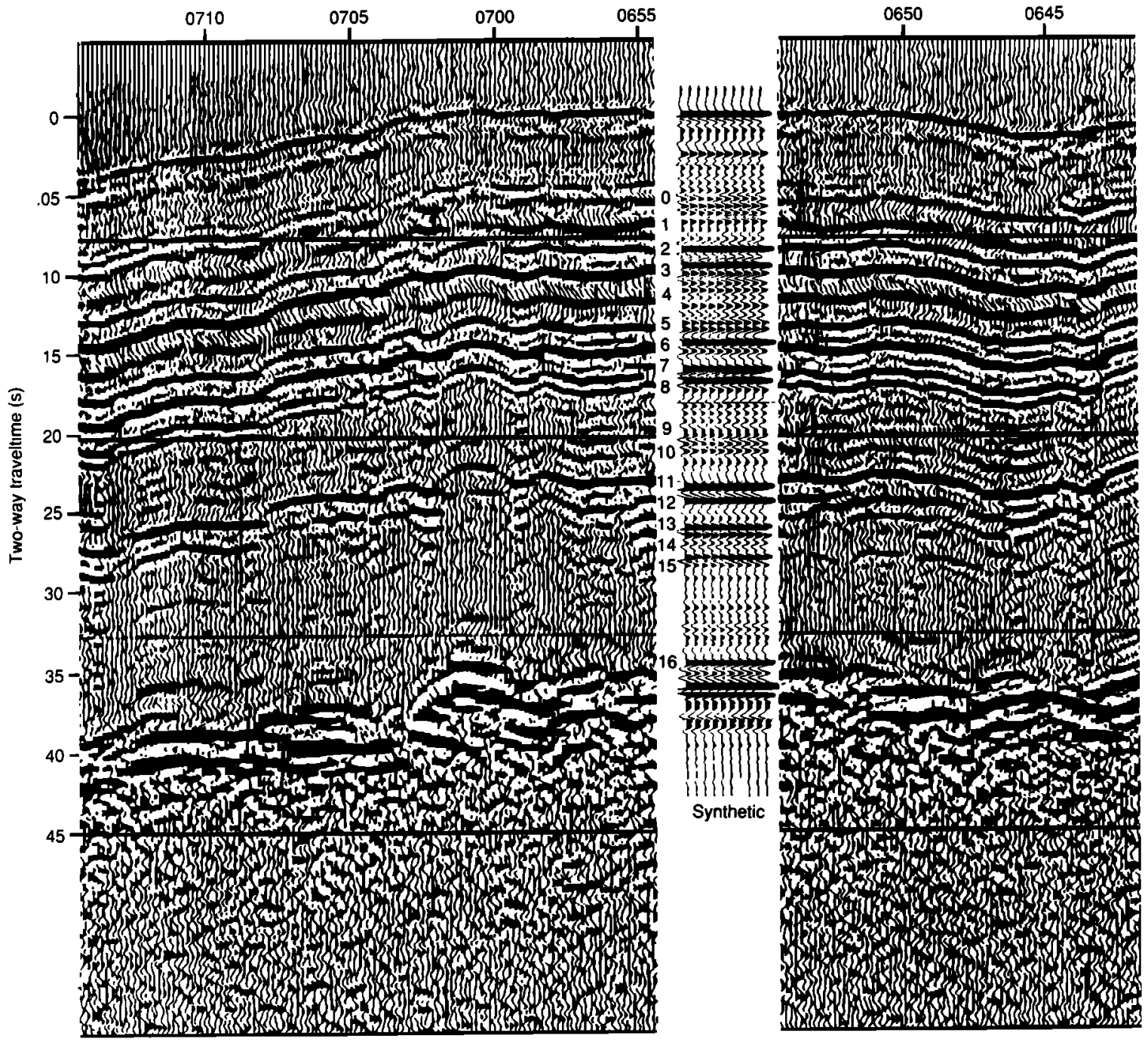

Fig. 6. R/V Thomas Washington 80 cubic inch watergun seismic profile across ODP site 844. The record in the middle of the section is a synthetic seismogram generated from the impedance profile (Figure 5c) and digitized R/V Thomas Washington outgoing seismic pulse. Synthetic seismogram calculation assumes plane waves and no multiples. Major regional reflectors labeled 0 through 16 refer to lines on Figures 5a-5c, 7a and $7 b$. 
TABLE 1. Site 844 Seismic Reflectors

\begin{tabular}{|c|c|c|c|}
\hline $\begin{array}{l}\text { Reflector } \\
\text { Number }\end{array}$ & $\begin{array}{l}\text { Age, } \\
\mathrm{Ma}\end{array}$ & $\begin{array}{l}\text { Equivalent Reflector } \\
\text { [Mayer et al., 1986] }\end{array}$ & $\begin{array}{l}\text { Correlative Paleoceanographic Events } \\
\text { [from Mayer et al., 1986] }\end{array}$ \\
\hline 0 & $6.7-7.0$ & 1M-B & $\begin{array}{l}\text { Vail event } \\
\text { general climate degradation } \\
\text { shoaling of the CCD } \\
\text { Increased microfossil provincialism }\end{array}$ \\
\hline 1 & $8.0-9.3$ & lM-P & $\begin{array}{l}\text { Vail event } \\
\text { major cooling } \\
\text { increased N. Pacific silica deposition } \\
\text { increased microfossil provincialism } \\
\text { high amplitude carbonate oscillations }\end{array}$ \\
\hline $\begin{array}{l}2 \\
3 \\
4 \mathrm{a} \\
4 \mathrm{~b} \\
5 \\
6 \\
7 \\
8 \\
9 \\
10 \\
11\end{array}$ & $\begin{array}{l}9.7-9.9 \\
10.5-10.6 \\
10.9 \\
11.1-11.2 \\
11.3-11.5 \\
11.7-11.8 \\
12.1-12.2 \\
12.2-12.3 \\
13.0-13.1 \\
13.3-13.5 \\
13.9-14.0\end{array}$ & lM-P & \\
\hline & $14.1-14.3$ & $\mathrm{mM}-\mathrm{R}$ & $\begin{array}{l}\text { Vail event } \\
\text { high-latitude cooling } \\
\text { faunal changes } \\
\text { ice buildup in Antarctica } \\
\text { intensification of AABW }\end{array}$ \\
\hline $\begin{array}{l}13 \\
14 \\
15\end{array}$ & $\begin{array}{l}14.5-14.7 \\
14.9 \\
15.2\end{array}$ & & \\
\hline 16 & 17 & eM-L & $\begin{array}{l}\text { Vail event } \\
\text { closing of Tethys } \\
\text { Monterey Carbon excursion } \\
\text { intensified Pacific upwelling } \\
\text { Norwegian Sea overflow into N. Atlantic }\end{array}$ \\
\hline
\end{tabular}

laboratory measurements (in the upper 50-100 m where there is no log data, Figure $5 \mathrm{~b}$ ) and multiplied by the sonic velocity to generate an acoustic impedance profile (Figure 5c). Reflectivity is then calculated from the acoustic impedance and convolved with a digitized version of the outgoing seismic pulse measured with a calibrated far-field hydrophone during collection of the site survey data. The resulting synthetic seismogram can then be compared to the original seismic data in order to understand how the complex geologic structure of the borehole is expressed in the seismic record (Figure 6). Using this simple approach, the major seismic horizons can now be associated with discrete geological events or groups of events (Table 1).

\section{RESULTS}

In the example presented (site 844 in the Guatemala Basin; Figure 6) it is clear that the major seismic events are associated with large contrasts in saturated bulk density that, in turn, are the result of major changes in carbonate content (Figure 7). The upper $50 \mathrm{~m}$ of the section is seismically transparent (Figure 6). This interval corresponds with a long (about 9.5 M.y.) period of relatively slow sedimentation during which the site was below the calcite compensation depth and thus did not accumulate carbonate. The interval from approximately 200-300 meters below sea floor (about 15-18 $\mathrm{Ma}$ ) is also relatively transparent seismically (Figure 6). In this case the lack of major seismic 


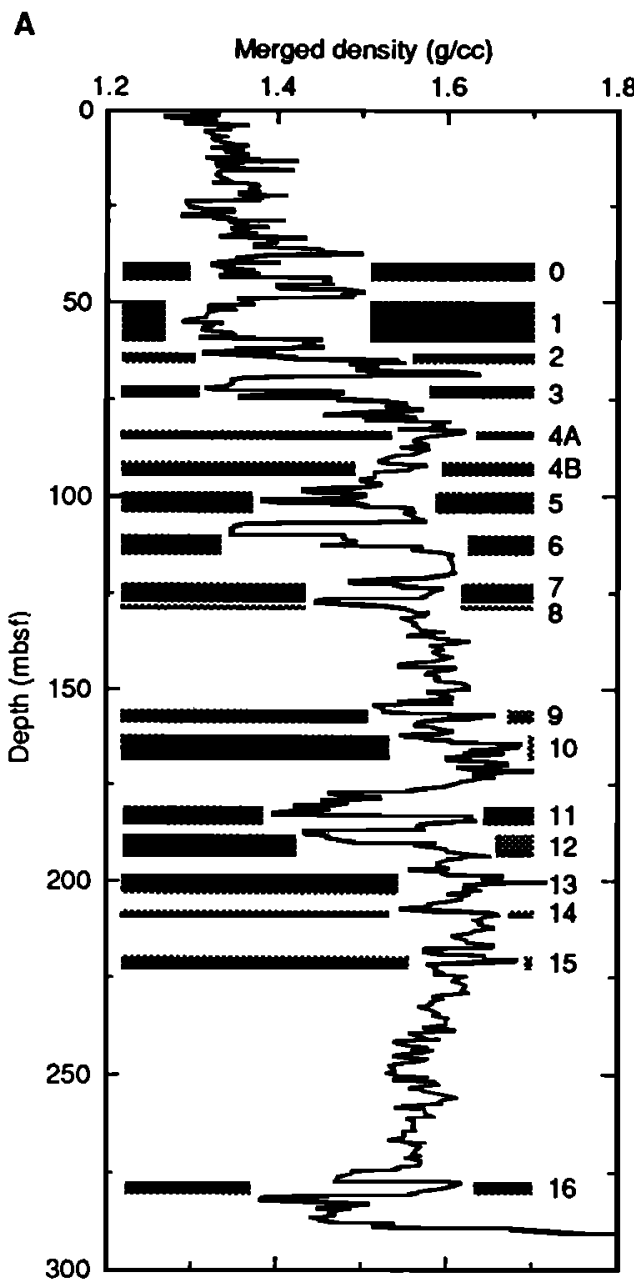

B 1.80

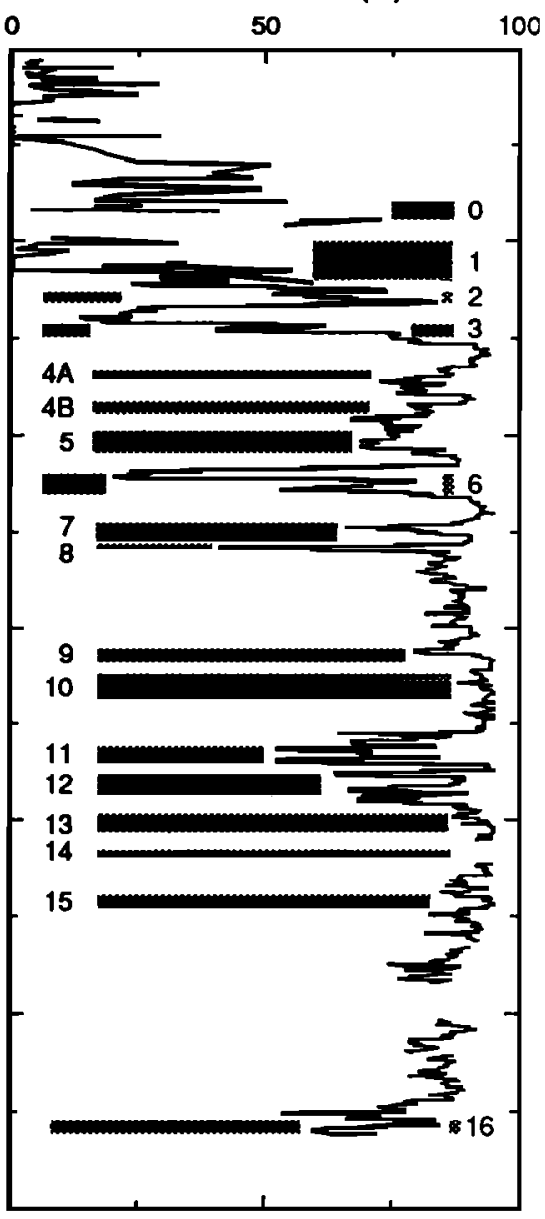

Fig. 7. Figure comparing (a) wet bulk density and (b) carbonate content of site 844 , showing that carbonate content is the primary factor controlling bulk density changes in the eastern equatorial Pacific [Mayer, 1991]. Major seismic events in the region are thus tied to carbonate events. Shaded lines show major seismic reflectors picked on Figure 6.

events is the result of consistently high carbonate values and little change in either velocity or density (Figure 7). In contrast, the middle of the section (representing the period between about 9.5 and $15 \mathrm{Ma}$ ) is characterized by a number of well-defined seismic events that correspond nicely to large changes in carbonate content (Figure 7). The association of major seismic horizons with regional carbonate events has been demonstrated in both the central [Mayer et al, 1986] and western [Berger et al., 1992] equatorial Pacific. These earlier studies found that the major seismic horizons were synchronous over large areas and that they were related to reorganizations in ocean circulation that can be linked to major tectonic and sea level events. While some of these carbonate events probably represent times of enhanced dissolution, others may be related to major productivity events that are often expressed as monospecific laminated diatom oozes (A.E.S. Kemp and J.G. Baldulf, Laminated diatom ooze from the equatorial pacific: An indicator of massive Neogene productivity).

Preliminary analysis of leg 138 seismic data (Table 1) suggests that these same events are also expressed in the seismic stratigraphy of the eastern equatorial Pacific (and thus are oceanwide, if not global). Table 1 lists the seismic events from Figures 5 and 6 and compares them to the previous work of Mayer et al. [1986]. The late Miocene IM-P and the middle Miocene mM-R events of Mayer et al. [1986] are wellexpressed at site 844 , but many additional seismic events can also be traced. The identification of additional seismic events in the 
eastern Pacific sections is partly due to the higher resolution afforded by the higher sedimentation rates in the eastern part of the Pacific basin (the result of increased productivity). The events we see at an individual site may not be basin-wide but rather represent more local changes in sedimentation (e.g., surface water versus deepwater phenomenon). Indeed, one of the exciting potential paleoceanographic applications of high-resolution seismic stratigraphy is the separation of local from regional events and the three-dimensional mapping of the extent of local events. Finally, the identification of additional seismic events is also partly due to our ability to groundtruth seismic sections with logs in ODP. Earlier (Deep Sea Drilling Program) sites in the equatorial Pacific were not logged.

Leg 138 has demonstrated that the eastern Pacific also contains regional paleoceanographic features detectable in the seismic sections. In particular, the absence of carbonate in the late Miocene-Recent section of site 844 and other sites in the Guatemala Basin of the eastern Pacific (ODP site 845 and DSDP site 495) is now known to be confined to the deeper portions of this basin alone. In other sites outside the Guatemala Basin drilled by leg 138 and by DSDP, low carbonate contents are found only in an interval between about 10 and 7.5 Ma. Calibration of the seismic record by logging of drill holes will allow us to trace the regional extent and timing of the Guatemala Basin carbonate anomaly.

The ability to view the seismic record in terms of paleoceanographic events thus allows us to extend our paleoceanographic interpretations well beyond the geographic constraints of the borehole. As we identify and trace specific paleoceanographic events in the seismic record, we can begin to explore the response of the ocean through gradients of latitude, productivity, or depth. The key to the success of this approach is the critical link between the borehole and the seismic record that is provided by careful downhole logging.

\section{REFERENCES}

Berger, W. H., L. W. Kroenke, L. A. Mayer, J. Backman, T. Janecek, L. Krissek, M. Leckie, and M. Lyle, The record of Ontong Java Plateau: Main results of ODP Leg 130, Geol. Soc.Am. Bull.. 104, 954-972, 1992.

Hamilton, E. L., Variations of density and porosity with depth in deep-sea sediments, $\mathbf{L}$. Sediment. Petrol. 46, 280-300, 1976.

Heath, G. R., R. B. Kovar, C. Lopez, and G. L.
Campi, Elemental composition of Cenozoic pelagic clays from Deep Sea Drilling Project Sites 576 and 578, western north Pacific, Initial Rep. Deep Sea Drill Proj. 86, 1985.

Martinson, D. G., W. Menke, and P. Stoffa, An inverse approach to signal correlation, $\underline{\underline{J}}$. Geophys. Res. 87, 4807-4818, 1982.

Mayer, L., Extraction of high-resolution carbonate data for paleoclimate reconstruction, Nature. 352, 148-151, 1991.

Mayer, L. A., T. H. Shipley, and E. L. Winterer, Equatorial Pacific seismic reflectors as indicators of global oceanographic events, Science. 233, 761-764, 1986.

Miller, K. G., and B. E. Tucholke, Development of Cenozoic abyssal circulation south of the Greenland-Scotland Ridge, in Structure and Development of the Greenland-Scotland Ridge, edited by M. H. P. Bott, S. Saxov, M. Talwani, and J. Thiede, pp. 549-591, Plenum, New York, 1983.

Ruddiman, W. F., D. Cameron, and B. M. Clement, Sediment disturbance and correlation of offset holes drilled with the hydraulic piston corer: Leg 94, Initial Rep. Deep Sea Drill Proj. 94, 615-634, 1987.

Tucholke, B. E., Geologic significance of seismic refledtors in the deep western North Atlantic, Soc. Econ. Paleontol. Mineral Spec. Publ. 32, 23-37, 1981.

Tucholke, B. E., and G. S. Mountain, Seismic stratigraphy, lithostratigraphy, and paleosedimentation patterns in the North American Basin, in Deep Drilling Results in the Atlantic Ocean: Continental Margins and Paleoenvironment, Maurice Ewing Ser., vol. 3, edited by M. Talwani, W. Hay, and W. B. F. Ryan, pp. 58- , Washington, D. C., 1979.

S. Bloomer and L. Mayer, Ocean Mapping Group, University of New Brunswick, P.O. Box 4400, Fredericton, N.B. Canada E3B 5A3.

K. Dadey, Hawaii Institute of Geophysics, University of Hawaii at Manoa, 2525 Correa Rd., Honolulu, HI 96822.

T. Hagelburg and N, Pisias, College of Oceanography, Oregon State University, Corvallis, OR 97331.

M. Lyle, Borehole Research Group, LamontDoherty Geological Observatory, Columbia University, Palisades, NY 10964.

(Received May 29, 1992; revised September 1, 1992; accepted September 1, 1992.) 